\title{
Kogumisvõistlused pärimusliku ajaloo uurimises ${ }^{1}$
}

\author{
Jyrki Pöysä
}

Teesid: Artiklis esitatakse küsimusi kogumisvõistluste raames kogutud kirjalike kaastööde kui spetsiifilise pärimusliku ajaloo uurimisallika kohta. Selliste tekstide uurimisest väljakasvanud töökogemusele tuginedes analüüsitakse suulise ja kirjaliku esitusviisi (meenutamise) erinevusi ning sellest tulenevaid kirjaliku teksti tõlgendusmeetodeid. Arutletakse kirjalike kaastööde žanriproblemaatika üle.

Märksõnad: eluloouurimine, kogumisvõistlus, kogumisvõistluse kirjalikud kaastööd, pärimuslik ajalugu, pärimusžanr, suuline ajalugu, suulise ajaloo intervjuu, suuline ja kirjalik kultuur (meenutamine)

Pärimusliku ajaloo uurimine (soome k muistitietotutkimus) seostub rahvusvaheliselt suunaga, mida nimetatakse ingliskeelse mõistega oral history research (suulise ajaloo uurimine). Kui pärimusliku ajaloo allikad võivad olla nii suulised kui ka kirjalikud, siis suulise ajaloo identiteeti määratlevad endastmõista suulised intervjuumaterjalid. Intervjueeritava ja intervjueerija dialoogi põhjal luuakse pilt minevikust, kus domineerib narratiivsus ning intervjueeritava isiklik kogemuslik suhe ajalooga (vrd Portelli 1998: 25). Oma kogemuse kirjeldus on alati ka elulooline kirjeldus, mis selgitab pärimusliku ajaloo uurimise tihedat seost eluloouurimisega. Neid kahte uurimisviisi eristab teineteisest siiski fookus: eluloouurijal ei ole ainese mitteametlik, mälul põhinev ajalookäsitus nii kesksel kohal kui pärimusliku ajaloo uurijal, kelle huviobjektiks võivadki näiteks olla erinevad ajalookäsitlused. ${ }^{2}$

Käesolevas artiklis vaatlen, kuidas uurimise lähtekohad muutuvad, kui meenutused esitatakse suulise intervjuu asemel hoopis paberil. Soome pärimusli$\mathrm{ku}$ ajaloo uurimistraditsioonide piires ei ole kirjalikku meenutamist peetud kuigi oluliseks ning sellise teabehankimisviisi erijoonte ja tõlgendamisega seotud metodoloogiliste lahendustega ei ole (uusimaid uurimissuundi arvestamata) kuigivõrd tegeldud. ${ }^{3}$ Oma uurimistöös olen pärimusliku ajaloo kirjalike materjalidega kokku puutunud alates metsatöödega seotud pärimuse ja pärimuslikku ajalugu käsitleva väitekirja koostamisest (Pöysä 1997). Kuid seoses 
pärimusliku ajaloo projekti “Joensuu kohad" kogumisvõistluse korraldamise ja selle põhjal antoloogia koostamisega (Kaarlenkaski et alii 2005) olen põhjalikumalt süvenenud nendesse probleemidesse, mis tulenevad nimelt materjali kirjalikust loomusest. Varem tundus kirjalik eneseväljendus iseenesestmõistetav - igaüks oskab ju lugeda. Tõlgenduslikud probleemid keskendusid siis käekirjade dešifreerimisele.

Käesoleva artikli eesmärk on käsitleda kirjaliku ja suulise esitusviisi erinevuste mõju materjali tõlgendamisele, tuginedes oma senisele uurimiskogemusele. Seega ei ole tegemist mitte ülevaatega olemasolevatest teadustöödest vaid katsega pakkuda oma kogemustel põhinevat tööetappide liigendust, mis võiks toetada kogumisvõistluste materjalide uurimist, kui sellega algust tehakse. ${ }^{4}$ Artikli rõhuasetus lähtub minu seotusest folkloristika (haridus) ja arhiivindusega (töökoht). Olen üleskutsete vastustena kirjutatud või intervjueerides kogutud uurimismaterjalide suhtes neutraalne: ma ei pea üht meenutamise vormi teisest paremaks, küll aga pean tähtsaks tähelepanu pööramist nende vormide erinevustele. Märgates erinevusi, näeme paremini ka sarnasusi ehk seda, kus suuline või kirjalik vorm ei erine teineteisest, vaid isegi osaliselt kattuvad.

Esmalt käsitlen seda, kuidas mõjub meenutamisele nii meenutamissituatsioon (koos selles osalejatega) kui ka vahend, kuidas mälestused salvestatakse. Seejärel tutvustan kahte meetodit, mis võimaldavad kogumisvõistluste kau$\mathrm{du}$ saadud heterogeenset tekstimaterjali süstematiseerida. Isiklikest ja oma lähikondsete kogemustest jutustades teevad kirjutajad teksti vormi ja väljendusviisi puudutavaid valikuid, millest suurem osa on pigem intuitiivsed kui teadlikud. Laiendatud žanrianalüüs annab võimaluse kirjeldada tekstidele iseloomulikke kirjanduslikke jooni. Vormi valikuga antakse vihjeid ka sisu tõlgendamiseks ning infot kirjutaja enda suhtumisest oma ülesandesse. Teksti mitmeteemalisust vaatlen jutustuse analüüsi kaudu: selle abil eristatakse tekstis kirjeldatud sündmuste ajalisi ja põhjuslikke seoseid ning jutustaja enda suhet kujutatavatesse sündmustesse.

\section{Küsime rahvalt}

Sellist pealkirja kandis Helsingi ülikooli rahvaluule osakonna 1992. aasta sügisel korraldatud seminar, kus arutleti kogumisvõistluste ja küsitluste tulemusel saadud kirjalike materjalide kui folkloristliku uurimisallika senise kasutuse üle. ${ }^{5}$ Sama temaatika lahkamist jätkati järgmisel aastal Soome Kirjanduse Seltsi lehes Elias. Lehe viimaseks jäänud numbris 4/1993 avaldati Satu Apo kirjutis, kus ta andis hinnangu seni "nähtamatule" materjalikogumismee- 
todile ja esitas metodoloogilisi tähelepanekuid selle allika tõlgendamiseks. S. Apo artikkel ja selle paar aastat hiljem avaldatud täiendatud versioon (Apo 1995) sisaldas olulisi terminoloogilisi ettepanekuid, muu hulgas "teemakirjutamise" ja "kirjutava jutustaja" mõisteid. ${ }^{6}$ Kõige olulisem on aga see, et tegemist on kirjutada palutud, ${ }^{7}$ mitte juba olemasolevate isiklike tekstidega (näiteks kirjad ja päevikud). Temaatilisus viitab sellele, et kirjutamise teema on alati mingil moel piiratud.

Ja rahva käest on ka küsitud. Praeguseks on juba ainuüksi Soome Kirjanduse Seltsi rahvaluulearhiiv korraldanud üle kahesaja kirjutusvõistluse ja vastajate võrgustikule saadetud küsitluse. ${ }^{8}$ Sel moel saadud materjal on pakkunud ainest peaaegu viiekümnele antoloogiale ja suuremale uurimistööle, arvestamata üksikartikleid (vt Laaksonen \& Saarinen 2004: 28-30). Rahvaluulearhiivi kogumistööst innustatuna ning koos kvalitatiivsete meetodite ja narratiivse uurimisviisi levikuga on teemakirjutiste abil materjali kogumist kasutatud mujalgi. Tänapäeval võib kohata mitmesuguseid üleskutseid, mille eesmärk on hankida kirjutamisel põhinevat materjali, seda erinevates teadus- ja publikatsiooniprojektides, näiteks sotsiaalteadustes. Üks viimaseid üleskutseid, mida juhtusin nägema, oli Helsingi Stockmanni kaubamaja uksel 2005. aasta novembris. Sellel plakatil paluti klientidel kirjutada kaubamajaga seotud meeldejäävatest kogemustest. Seegi projekt mahub pärimusliku ajaloo uurimise raamesse, on ju paljud selle valdkonna teadusprojektid saanud alguse väljaspool teadust tärganud huvist. Võimalik, et idee koguda klientidelt ja klientide kohta lugusid pärines Helsingin Sanomates pealkirja all "Eriline sündmus" avaldatud lehelugejate argielukirjeldustest-lühilugudest, mida on ajalehe arhiivi kogunenud juba tuhandete kaupa ning mille põhjal on välja antud ka omaette antoloogia (Karumo 2004, vt ka http://www.hs.fi/extrat/ erikoinentapaus/).

Üleskutsete ja kogumisvõistluste teel saadud materjale on kasutatud alates 1970. aastatest teadusharudes, milles on rakendatud pärimusliku ajaloo ja eluloo mõisteid, seda seoses kvalitatiivsete meetodite omaksvõtu ja teadusharude metodoloogilise uuenemisega sel perioodil. Võtmeprojektiks võib pidada Vantaa elanike omaelulugude kogumist 1978. aastal, mille olulisust antud kontekstis rõhutab eelkõige see, et tegemist oli kirjutusvõistluse vormis läbiviidud projektiga. Tavapärasem ja ajastule iseloomulikum oleks olnud hankida eluloomaterjale suuliste intervjuudena. ${ }^{9}$ Kirjalike omaelulooliste materjalide kasutamise üle on pärimusliku ajaloo uurimise seisukohalt olulist metodoloogilist diskussiooni peetud ühiskonnateadlaste eestvedamisel (nt Roos 1987: 12 14; Piela 1993; Vilkko 1997; Hyvärinen et alii 1998). Folkloristid olid alguses nende projektide juures peamiselt kogumisvõistluste kaaskorraldajatena, üht- 
lasi analüüsisid nad oma kogemusi kirjeldava materjali folkloristlikku kasutusväärtust (Virtanen 1982; 1993).

Rahvaluulearhiivi kogumistegevuse käigus kirjutatud elulugude ja pärimusliku ajaloo kogumine on loomulik jätk arhiivi korrespondentide võrgustikule ja laiale üldsusele suunatud kogumisprojektidele, kus pärimusliku ajaloo ja eluloo mõistete asemel või kõrval on esinenud ka pärimuse mõiste või mõni selle alamõiste, näiteks suulise pärimuse žanr. ${ }^{10}$ Esimesi kordi viidati pärimusele ja pärimuslikule ajaloole kui omavahel seotud mõistetele 1966. aastal korraldatud kogumisvõistlusel "Aastatel 1917-1918 toimunud sündmused rahva mälus ja pärimuses" (Vuosien 1917-1918 tapahtumat kansan muistissa ja perinteessä), mis oli keskseks allikaks Ulla-Maija Peltoneni (1996) ja Outi Fingerroosi (2004) väitekirjades. Pärimuslikule ajaloole viitava pärimuse mõiste kasutamist seletab ehk see, et tööliste pärimusliku ajaloo uurimisrühm oli oma tegevust alustanud juba 1960. aastal ning sinna oli kaasatud ka rahvaluulearhiivi töötajaid (vt Peltonen 1985; Pöysä \& Timonen 2004).

Folkloristi ette kerkivad metoodilised raskused eristada pärimusmaterjalides tõsieluna tõlgendatavat rahvapärast ajalugu materjali võrdlemise käigus folkloorseks osutunud materjalist näitavad ka pärimusliku ajaloo uurimist vähemteaduslikuna. Folkloristi vaatenurk pärimuslikule ajaloole kujuneb seega märkamatult konstruktiivseks, sündmuste realistlikus kirjelduses kahtlevaks (vt Beiner 1999; Fingerroos \& Haanpää 2006; Ukkonen 2006). See, et enesekohane materjal on siiski ainult osa kogu narratiivsest kogemuspildist, on sageli nähtav juba hoolikal lugemisel, aga ka loogiliselt tuletades: omaenda kogemus on nagu pulk suhkruvatis, mis hoiab püsti kogu jutustuse ülesehituseks vajalikku taustainfot, kuuldut või oletatut (vrd Korkiakangas 2005: 136-137).

Kirjutamisüleskutse kasutamine materjali kogumises eeldab ettekujutust lugevast ja kirjutavast rahvast või vähemalt sellise sotsiaalse kihi olemasolust, kes suudab ise kirja panna kogumisprojekti korraldajate poolt palutud materjali ning soovib olla kas intervjueerija või oma meenutuste kroonik (vrd Apo 1993: 14). Kuigi esimene kogumisüleskutse avaldati Soomes juba 19. sajandi keskel, hakati uuesti inimesi üles kutsuma oma mälestusi ja teadaolevat pärimust kirja panema alles 20. sajandil, kui toimus pärimuse, rahvaluule, rahvateaduse (etnoloogia) ja teiste seda tüüpi mõistetega seotud kogemuslik avanemine. Isiklik või isikule viitav informatsioon ehk see, mida varem taheti tõrjuda kogumisobjekti piiridest taustainfoks, sai oluliseks eelkõige aastatel 1980-1990 või muutus isegi esmaseks kogumis- ja uurimisobjektiks (vt täpsemalt Pöysä \& Timonen 2004).

Kirjaoskusele ja kirjutamisvalmidusele toetuvad kogumisvõistlused muutsid võimalikuks selle, et enesekohast kogemust sai kirjeldada ilma vahetu kontaktita koguja ja informandi vahel. Suulise ajaloo (kui pärimusliku ajaloo- 
ga seotud uurimisviisi) vaatepunktist on olukord vastupidine: intervjueerimise üheks väärtuseks on peetud just nimelt isiklikku kokkupuudet informantide ja nende elukeskkonnaga. Kirjalik mälestuste talletamine kajastab postmodernistliku ühiskonna paradoksaalset olukorda: samal ajal, kui privaatsuse kaitse on juriidiliselt tugevam kui kunagi varem, võimaldavad avalik tuntus ja uute tehnoloogiate kasutamine isikute äratundmist varasemast enam. Suulise ajaloo uurimisel, selle kriitilise (ja ka avalikult poliitilise) huviasetuse raames eeldati, et diktofon loob võrdõiguslikkust ja annab sõna neile, kellel varem ei olnud võimalust oma kogemust ühiskonnas esile tuua (Thompson 1978; Dunaway 1996). Kaasaskantava salvestustehnoloogia võimaldatud kriitiline realism avaldus ka 1960. aastate dokumentalistikas cinema verité liikumisena, mille kokkupuutepunkte suulise ajaloo (oral history) liikumisega tasuks lähemalt uurida. Radikaliseeruv suulise ajaloo liikumine nägi teadlase või intervjueerija rolli vahendajana, omamoodi ämmaemandana, kes toimetas suulise kultuuri esindajate elukogemused teisele poole piiri, kirjaliku kultuuri valda.

Idee vahendajarollist, mille järgi suulise ajaloo uurijad eeldasid, et nii antakse intervjueeritavatele omakasupüüdmatu mõjuvõim (ingl empowerment), on uuema naisuurimuse ringkondades kahtluse alla seatud. Teadlane või koguja tegutseb harva, kui üldse, täiesti omakasupüüdmatult: tal on oma huvid, mis ei pruugi tingimata kokku langeda intervjueeritavate eesmärkidega (Oinas 2004: 213-218; Ikonen \& Ojala 2005: 18). Väidan siiski, et pärimusliku ajaloo uurimises on empaatiline lugupidamine intervjueeritavate suhtes olnud valdavam kui rahvapärimuse kogumises üldiselt. Huvi isikliku vastu eeldab ka eetilist juurdlemist, erinevalt suhtumisest rahvapärimusse kui kollektiivsesse nähtusesse.

Helisalvestusaparaadi abil toimuva tekstiloome taga oli suulises ajaloos valdav ka arusaam rahva keelelisest ebavõrdsusest. Haritud, kirjutama ja lugema harjunud rahvakihtidel on rohkem võimalusi oma häält ühiskondlikult kuuldavaks teha, sest nende keeleline väljendus on retooriliselt usutavam ning neil on juba olemas oma avaldamiskanalid. Seevastu füüsilise töö tegijal, kes ei oska enamasti rohkem kirjutada kui oma nime, ei ole võimalust end kirjaliku kultuuri piires märgatavaks teha. Radikaliseerunud suulise ajaloo uurimine võttis oma kaitse alla loomulikult viimase. Teadlased nägid oma ülesandena tuua suuline kultuur kirjaliku kultuuri ruumi. Kummatigi on see teatud mõttes vastuolus nende samade teadlaste seisukohaga anda suulisele väljendusele eriline tähendus (vrd Portelli 1998: 34).

Väljenduslik ebavõrdsus tuleb esile ka siis, kui kõneldakse kirjutatud mälestustest. See ilmneb kirjutajate enesemääratlustes: oma teksti ja iseennast kirjutajana alahinnatakse ning kirjutamise eesmärgiks ei peeta mitte kogumisvõistluses osalemist vaid ajaloolise tõe, vähemkindlustatute hääle ja koge- 
muse esiletoomist (vt lähemalt nt Pöysä 1997: 42-44). Kuigi Soome Kirjanduse Seltsi kogumisvõistluste ametlikuks eesmärgiks ei ole olnud võimu andmine kirjutajatele, on saadud auhinnad (näiteks 1969. aasta rändtööliste pärimuse kogumisvõistluse raames said kõik osalejad auhinna) ja oma teksti nägemine antoloogias kahtlemata innustanud kirjutajaid teistelgi kogumisvõistlustel osalema ning see on avaldunud ka nende kirjutajaidentiteedi tugevnemises.

\section{Kirjutamine kui meenutamisolukord}

Mille poolest erinevad üksteisest kirjutades ja intervjuu käigus kõnena salvestatud mälestused ning kuidas need erinevused mõjutavad materjali tõlgendamist? Keeleuurija vaatepunktist ei ole olemas ühtegi üksikomadust, mis eristaks kirjakeelt kõnekeelest (Chafe \& Tannen 1987: 391). Näiteks teaduslikus töös kasutatavaid suulise ja kirjaliku teksti liike - vestlus, loeng, kiri, teaduslik artikkel vms - omavahel võrreldes on täheldatud, et kõne mõningates vormides esineb kirjakeelele omaseid keerulisi süntaktilisi konstruktsioone, samas võib kirjutatud tekst mõnikord olla vägagi kõnekeelne, piiratud sõnavaraga ning süntaktiliselt konstruktsioonilt ahelvormis (ja-ja stiilis) arenev (Chafe \& Danielewicz 1987). Kirjutamine võib olla ühelt poolt elektroonilise jututoa teksti sarnaselt spontaanne, peaaegu redigeerimata mõttevoo väljendamine, teisalt aga vägagi läbimõeldud, mitu korda töödeldud teksti loomine. Intervjuu võib olla kas vabas vormis vestlus või muutuda peaaegu kirjakeelseks formaalseks mõttevahetuseks. Olukorrakohased tegurid, eelkõige see, kuidas intervjueeritav või kirjutaja oma elukogemusest tulenevalt olukorda tajub, on jutustuse lõpliku kuju mõjutajatena väga olulised. Ka video- või filmikaamera kohalolek intervjuul võib lähendada suulist meenutust kirjaliku eneseväljenduse reeglitele (Portelli 1998: 33).

Kirjutamissituatsiooni olemuslik eripära võib selgemini esile tulla, kui võrrelda omavahel kirjutamise ja intervjueerimise efektiivsusmomente. Kirjutades meenutamise keskseteks joonteks on privaatsus, vahetu kommunikatsiooni ja seega ka otsese interaktiivse suunamise puudumine (vrd näiteks intervjueerija küsimused ja tagasiside intervjueerimisel), võimalus jaotada kirjutamissituatsioon mitmeks etapiks, võimalus teksti toimetada, ${ }^{11}$ võimalus valida kirjutamiseks aeg ja koht ning tava kirjutada teksti kujuteldav vastuvõtja (tekstisisene dialoogilisus). ${ }^{12}$ Ulla-Maija Peltonen on samas kontekstis kasutanud kirjandusteaduse mõistet 'siselugeja', mis sobib tekstisisese dialoogilisuse kirjeldamiseks väga hästi (Peltonen 1996).

Kirjutamissituatsiooni privaatsus on nii endastmõistetav, et selle tähendusele teksti analüüsis ei osata alati tähelepanu pööratagi. Kirjutamine ei ole 
üksnes privaatne, vaid ka intiimne. Intiimsus avaldub näiteks selles, et kirjutaja peab pealetükkivaks, kui keegi kirjutamist kõrvalt jälgib. Alles valmis tekst võib kirjutaja otsusel muutuda avalikuks. Ja ka siis kaitseb kirjana kirjutatud teksti postisaladus, millele vastav seadusliku alusega regulatsioon aga puudub vestluse või intervjuu valdkonnas. Suuliselt edastatud informatsiooni kaitseb ainult sotsiaalne sanktsioneerimine, süüdistus kuulujuttude levitamises.

Kuidas mõjutab meenutamist ja selle kaudu loodud teksti kirjutamissituatsiooni privaatsus? Kui tekst on mõeldud lugemiseks kellelegi teisele, ei pruugi situatsioon teksti pihtimuslikkust sugugi suurendada. Seevastu väljastpoolt tulevate küsimuste ja tagasiside puudumine soodustab tõenäoliselt teksti isesuunduvust, assotsiatiivseid seoseid teemade vahel. Olukorra privaatsus tähendab ka võimalust adresseerida tekst kujuteldavale vastuvõtjale, kes võib intervjuu- või vestlusolukorras konkreetselt kohalolevate isikute asemel olla hoopis mõni veel sündimata tulevikuinimene või abstraktsioon.

Meenutusele tuginev kirjutamine ei ole siiski päris vaba teadvusvool. Kogumisvõistluse teema ja kogumisüleskutsena avaldatavad, enamasti üsna lihtsad vastamisjuhised suunavad kirjutamist ja täidavad mingis mõttes sama rolli nagu on intervjueerijal intervjueerimissituatsioonis. Ometi on kirjutajal siiski suurem vabadus ise valida oma kirjutamissuunda: puudub intervjueerija, kes juhiks kirjutajat tagasi "asja juurde". Ka jääb enda valitud kirjutamissituatsioonis tagaplaanile vahetute suhtlussituatsioonide ja eelkõige intervjuuga kaasnev püüd sobitada oma arusaamu intervjueerija tõeliste või eeldatavate arusaamadega (vt Bauman \& Briggs 1990, 71). Ühtlasi on kirjutajal voli oma kirjutise ärasaatmisest loobuda. Lauasahtel või paberikorv on oma tekstile hinnangu andmisel väga realistlik alternatiiv.

Kirjutamise teine oluline loomistingimus on võimalus kirjutada teksti mitmes etapis, lugeda ja parandada varem kirjutatut ning täiendada varasemaid tõlgendusi. Valitud tehnikast olenevalt võib teksti uuesti sõnastamine olla vägagi lihtne. Kirjutamine võimaldab paremat kontrolli oma mõtete väljendamise ja teadliku minapildi säilitamise üle. Kui kirjutades loodav minapilt on intiimne (see ei ole sugugi alati nii: kirjutamise intiimsus ei ole seega otseselt seotud sisu intiimsusega), on see läbimõeldult intiimne, mitte spontaanne ülestunnistus ega keelevääratus, nagu seda võib ette tulla vaba õhkkonnaga intervjuusituatsioonis.

Võimalus lugeda oma mõtteid paberil või ekraanil ärgitab nende üle ka juurdlema ning käivitab pikemaajalise meenutusprotsessi, millele intervjuumeetodi kasutamisel vastab kõige paremini korduvatest sessioonidest koosnev süvaintervjuu. Seetõttu kujuneb kirjutamise ja omaeluloolise meenutamise omavaheline seos eriti põimunuks: tänu oma pikaajalisele, protsessilise- 
le loomusele kirjutamine lausa innustab autobiograafilist jutustamist. Eluloo autentse tõepärasuse üle juureldes ei tohi siiski unustada, et kirjutamine soodustab ka fiktiivsust: kui intervjuu käigus joonistub eelkõige välja situatsiooniline mina, siis kirjutamise tulemuseks on pigem kujuteldav mina, mis saab kirjutamissituatsioonist vabalt eemalduda, seda muidugi kirjutaja fantaasia ja mitmesuguste "biograafialepingute" (Lejeune 1989) sarnaste iseendale asetatud piiride ulatuses.

\section{Žanrianalüüs ja tekstide mitmekesisuse probleem}

Kogumisvõistluste käigus saadud materjalidega seonduv põhiprobleem kasutaja seisukohalt on materjali heterogeensus, selle mitmekesisus. Ei varieeru ainult kirjutiste pikkus ja kirjutamiseks kasutatud vahendid, vaid vahelduvad ka tekstide vorm ja stiil ning kõike seda mitte ainult erinevate kirjatööde, vaid ka ühe ja sama teksti ulatuses. Kuidas sellises mitmekesisuses orienteeruda? Kas piisab sellest, kui keskenduda ainult tekstide temaatikale, kirjutiste sisule? Järgneva teemaarenduse aluseks on lähtekoht, et vormiline kategoriseerimine aitab saada ülevaadet ka teksti sisust: žanrid on kommunikatiivsed, vorm viitab sisule ja suunab nii kogu lugemisprotsessi vältel ka tõlgendust (Todorov 1984: 80; Hanks 1989: 98). Tekstiliigid ei tohiks siiski saada peamiseks uurimisobjektiks: žanride määramine tugineb erinevatele kriteeriumitele ning üks ja ainuõige, ühtsetel kriteeriumitel põhinev liigitus puudub: seda ei ole suudetud luua isegi suulise pärimuse valdkonnas, ammugi siis kõiki väljendusvorme ühendava süsteemina.

Kirjutises "Oral History as Genre” (Suuline ajalugu kui žanr) vaatleb Alessandro Portelli (1998) žanri mõiste olemust mitme nurga alt. Ühest küljest on suuline pärimus juba iseenesest teiste suuliste ja kirjalike žanrite mõjusfääris väljakujunenud väljendusviis, kus kõnelejad ja uurija (“ajaloolane”, nagu Portelli oma uurimissubjekti nimetab) kasutavad ära kogemusjutustuse, folkloori ja meedia pakutavaid teemasid ja vorme. ${ }^{13}$ Tulemuseks on “žanridest koosnev žanr" või kompositsiooniline žanr (ingl genre of genres, compositional genre), Mihhail Bahtini termineid kasutades kompleksne või teisene žanr (vene složnõi / vtoritshnõi žanr; ingl complex/secondary genre). ${ }^{14}$ Teisalt võib suulist ajalugu pidada ka omaette žanriks, diskursuse liigiks, mis põhineb intervjueeritavate ja uurija omavahelisel kommunikatsioonil ning mille lähtepunktiks on suuline kultuur, aga sihtpunktiks kirjutatud tekst (Portelli 1998: 23-25). ${ }^{15}$

Ka pärimusliku ajaloo kirjalikku materjali saab žanriliselt liigitada samade põhimõtete alusel. Kogumisvõistluste käigus saadetud kaastöödes sisaldub suulise ja kirjaliku teksti žanre, mis tulenevad kirjutaja haridusest, kirjutamisko- 
gemusest ja vastamisstrateegiast. ${ }^{16}$ Kirjalike kogumisvõistluste vastamisjuhendis - needki moodustavad antud kontekstis omaette olulise žanri ${ }^{17}$ - rõhutatakse enamasti teksti kui dokumendi väärtust. Ilukirjanduslikke väärtusi peetakse juhendites teisejärgulisteks ning kaastööde hilisemal hindamisel peetakse lausa segavaks, kui teksti kogemuslikkus või muu dokumentaalsus ilukirjanduslikkuse tõttu kannatab. Võib väita, et erinevalt ilukirjandusest, kus kirjaniku eesmärk on kombata eneseväljenduse piire, on kogumisvõistluse eesmärk leida žanre ja siis neid žanripiire aktsepteerida. Alati see kirjutajatel siiski ei õnnestu (või ei ole see nende meelest lõppude lõpuks kuigi tähtis) ning teksti sees toimub mitmesuguseid kõrvalekaldumisi. Kuna tekstide pikkus varieerub ühest leheküljest mitmete sadadeni, võib olla kindel, et seal esineb ohtralt mitmesuguseid komplekssuse vorme.

Missuguseid žanre kogumisvõistlusele saadetud kaastööd meile siis tõlgendusvihjeks pakuvad? Rahvaluulearhiivi talletatud kogumisvõistluste tööde kohta on uurijale pakkuda üks žanriliigitus, pärimusžanrianalüüsist tulenev strukturaal-sisuline liigitus (vt Laaksonen \& Saarinen 2004: 95-96). Lugedes meeste pärimust oma väitekirja jaoks jätsin olemasolevad liigitused siiski kõrvale, kuna minu arvates ei hõlmanud need materjali selliseid erijooni, mida tekste lugedes keskseiks pidasin. Olin sunnitud looma oma klassifikatsiooni, kus ühendasin pärimusžanrianalüüsi teiste kriteeriumitega, leides neid muu hulgas teadvuse kirjeldamise kontekstualiseerimise ja praktiliste situatsioonide vallast ning lõin täiesti uusi klassifikatsioone, sealhulgas näiteks meeste pärimusainese seisukohast olulised huumorisituatsioonide, rituaalide, valetamise, kaardimängu, võistluste, vandumise ja kõneainete kirjeldused (vt Pöysä 1997: 395-399).

Meeste pärimuse kogumisvõistlusele laekunud kaastööde klassifitseerimine pärimusžanrianalüüsi abil pakub üsna napilt kriteeriumeid ning see tundub põhinevat juhuslikel alustel. Tekste hoolikamalt lugedes võib ka märgata, et kirjutaja vaatlusviisist tulenevalt tundub piir suulist pärimust kajastava folkloori ja kogemustel põhineva pärimusliku ajaloo vahel olevat hajuv. Rahvaluuleteemad võivad sattuda jutustaja vahetute kogemuste kirjeldustesse ning nende põhjal võib omakorda sündida üldistatud kirjeldusi, millel puudub seos jutustaja vahetu kogemusmaailmaga. Kui lugejal ei ole enam võimalust küsimuste abil taustainfot täpsustada, tugineb kirjelduste allikakriitika tekstihulkade tervikul ja muul uurimistööl põhinevale teabele. Kirjutiste võrdlemine, kontekstualiseerimine, võimaliku ja võimatu vaagimine ning mitmesuguste teiste materjalide kasutamine kirjeldatud piltide tõlgendamisel moodustavad sellisel juhul uurijale peamise analüüsivahendite komplekti. Rahvaluule ja pärimusliku ajaloo kõrvutamine avab uurijale vaatenurki, mis jäid eelnevalt seatud kategooriapiire järgides seni varju. Küsimus oma kogemuste müütili- 
susest ja üldise tõe suhtelisusest saab uue tähenduse, kui tõlgendamisel võetakse arvesse ka ilmselgelt folkloriseerunud ajalugu ehk rahvaluulet.

Pärimusliigianalüüs on mõeldud eelkõige suulise pärimuse süstematiseerimiseks, kuigi rahvaluulearhiivis rakendatakse seda ka kirjutatud tekstide analüüsimisel. Kirjakultuuri tekste iseloomustavad siiski teised žanrid, mis võivad küll tuleneda suulistest žanridest (vrd Todorov 1990), aga millel võib olla oma, juba aastatuhandete pikkune ajalugu (näiteks tragöödia ja komöödia). Kirjandusžanrid muutuvad (arenevad) jätkuvalt muuhulgas kirjandusväliste konventsioonide ja kirjanduse enda sisemise dünaamika mõjul (vt Tõnjanov 2001).

Kogumisvõistluse kirjutamise žanrid ei moodusta ka omaette ühtset žanrisüsteemi. Oluline koht kogumisvõistluste kaastööde žanrirepertuaaris on kirjadel, päevikutel ja biograafilistel kirjeldustel. Ka kooli emakeeleõpetuse mõjuga tuleb arvestada: paljud kirjutavad oma kaastööd otsekui koolikirjandit õpetaja antud teemal. Samuti on ilukirjandusel oma juurdunud žanrikonventsioon, nagu ka ajalehe- ja teabetekstidel. Kaugeleulatuvaid kirjalikke lahendusi esineb ka meenutuskirjutistes: mõni võib oma tekstis näiteks kasutada romaani kompositsiooni järgivat mõttekriipsude ja järellausetega dialoogi, teine aga kirjutab teksti ajaleheartikli stiilis, kus kogemuste enesekohasus peidetakse üldistavate väidete taha. Kolmas jällegi paneb paberile murdekeelse följetoni. Kõik need näited esinesid ka neis materjalides, mida mina uurisin.

Kui kogumisvõistluse korraldajaks on rahvaluulearhiiv, võib eeldada, et üks kirjanduslikke mudeleid, mida vastajad kasutavad, on luulevorm. Värsimõõdulistes kaastöödes kasutatakse näiteks kalevala värsimõõdu põhjal mugandatud alliteratsiooni, lõppriimi või modernistlikku vabavärssi. Eepilised luulekroonikad kui kirjanduslike harrastuste esinemisvorm tundub olevat eelkõige tuttav vanemale põlvkonnale. Värsimõõdu kaudu lähenetakse kirjaliku teksti prosoodia seisukohalt huvipakkuvale küsimusele: kuidas korvab kirjutatud tekst (näiteks hüüu- ja küsimärkide abil) helilisi kvaliteete (vrd Latvala 2005: 71-72).

Kas avaldatud pärimusliku ajaloo tekste võib pidada omaette žanriks? Suulisel materjalil põhineva pärimusliku ajaloo valdkonnas esindavad Paavo Rintala Sotilaiden äänet (Sõdurite hääled, 1966) ja Sodan äänet (Sõja hääled, 1967) minu arvates selgelt ühtset pärimusliku ajaloo žanri: Soome Yleisradio arhiivi talletatud sõduritega tehtud intervjuudest väljanopitud lahingusituatsioonide kirjeldused on järjestatud kronoloogiliselt mitmehäälseks sõjakirjelduseks nende silme läbi, kes selles sõjas osalesid. Soome Kirjanduse Seltsi rahvaluulearhiivi korraldatud kogumisvõistluste kaudu saadud tekstide põhjal kokkupandud antoloogiad moodustavad teatud mõttes omaette kirjandusliku žanri, mida teatakse ka väljaspool rahvaluulearhiivi püsikirjasaatjate ringi. ${ }^{18}$ Sellise 
kogumisvõistluse materjalil põhineva antoloogia toimetaja märkab peagi, et tekstid erinevad üksteisest üsna oluliselt kirjandusliku kvaliteedi poolest. Neil erinevustel ei ole kogumisvõistluste hindamiskomisjonide silmis kuigi suurt tähtsust, sest olulisemaks peetakse kirjutise etnoloogilist väärtust, kogemuslikkust või seda, kui aus tundub kirjeldus olevat (iseenesest raskesti määratletav faktor). Antoloogiat toimetades tuleb sellelegi aspektile tähelepanu pöörata: väga katkendlikke või kirjanduslikult nõrku kirjeldusi tavaliselt antoloogiates ei avaldata, kuigi need võivad uurimuse seisukohalt olla isegi väärtuslikumad kui ladusalt kirjutatud tekstid. ${ }^{19}$ Nii vormib hiljemalt materjali avaldamine sellest uue diskursuse žanri, mis sobib paremini kirjanduse konventsioonidega.

\section{Jutustuse analüüs: tekstiosade ja ajatasandite eristamine}

Tekstide jutustuslikkuse vaatlemine suunab tähelepanu tekstide sisemisele ülesehitusele, mis tugineb kogemuste ajalisele liigendusele. Kuidas kirjeldab sündmusi neis osalenu ja kuidas ta omistab endast lähtudes sündmustele tähendusi? Olen ühes oma paari aasta taguses artiklis (Pöysä 2003) visandanud infotehnoloogia kasutamise teemal loodud kirjalike meenutuste analüüsimudeli. Lähtepunktiks oli materjali lugemisega kaasnenud meelehärmi tekitanud tähelepanek, et kui mõned selgelt eristatavad jutustuse osad, nt Alessandro Portelli (1998: 24) terminit kasutades eluloolised anekdoodid välja arvata, on kirjutiste jutustavaid vorme raske määrata ja üksteisest eristada. Üks võimalus oleks olnud käsitleda teksti tervikliku jutustusena. Seda lähenemisviisi võinuks pidada õigustatuks sel määral, et juba kogumisvõistluse üleskutse iseenesest tegi ettepaneku jutustada, meenutada ja kirjeldada infotehnoloogiaga seotud kogemusi. Nii nagu selliste kogumisvõistluste puhul sageli kombeks, paluti seegi kord kirja panna ka juba valmis jutustusi: ("Kas olete kuulnud infotehnoloogiaga seotud anekdoote, lugusid või uskumusi? Pange ka need kirja!", vt Pöysä 2003: 181). Jutustavat diskursust julgustati seega looma kahel viisil: palvega esitada oma isiklikke kogemusi lugudena ja palvega meenutada juba valmis lugusid.

Kogumisvõistluse kaastöö käsitlemine tervikloona on põhjendatud samavõrra kui kirjandusteaduses näiteks romaani käsitlemine ühtse tervikuna. Ka tekstitüübiteooria toetaks sellist lähenemisviisi: kirjutiste puhul on tegemist spetsiifilise jutustava tekstitüübiga (vt Kauppinen \& Laurinen 1984; Virtanen 1992; Fludernik 2000). Loo süvalugemisel kätkeb selline lähenemisviis endas 
aga siiski probleeme: millised on kogumisvõistluse kaastöö need osad, mida ei saa lihtsalt liigitada jutustusteks ega ka komplekssema loo kui terviku osadeks (näiteks elulooliste pikaajaliste protsesside kirjeldused). Kui jutustuse mõistet nõnda käsitletakse, siis meenutab see jutustuse nägemist kõikjal. Ent see on uurimise seisukohalt probleemne: materjalipõhise uurimuse abivahendina kaotab mõiste siis oma tähenduse, kuna see hõlmab peaaegu kõike (vt Hyvärinen 2005).

Kirjalikke kaastöid lugedes võib näha, et neis on mitmeid üksikuid väikseid lugusid. Selliste lugude äratundmine tekstis viitab nähtusele, mida olen nimetanud jutustuse ühetasandilisuse mudeliks (kertomuksellisuuden yksitasomalli). Kogumisvõistluste tekstid võivad kirjutaja stiilist tulenevalt sisaldada selgepiirilisi teema tervikkäsitlusi või ka anekdootlikke lugusid, mida tähistatakse teksti metatasandi selliste viidetega nagu loo alustamine stiilis "mäletan üht korda, mis seda hästi iseloomustab" ja lõpetamine stiilis "pärast seda on olnud teisigi sarnaseid olukordi, aga need lahenesid iseenesest". Selliste lausetega osutab jutustaja ühe (või mitme) loo omadusele olla ühtse terviku iseseisvaks üksuseks, mis omakorda viitab sellele, et konkreetset tervikteksti (ehk jutustuse üht varianti) saab tunnetuslikult liigendada eraldiseisvateks osadeks. Helsingin Sanomate kogutud erilised juhtumid on just seda tüüpi jutustused, mida toimetaja on tõenäoliselt veel parasjagu silunud, et muuta need iseseisvateks lühilugudeks, ühe või kahe episoodi pikkusteks sündmuskirjeldusteks.

Selgepiiriliste sündmuslugude ja tervikteksti kui jutustuse vahele jääb aga avar jutustuslikkuse väli, mida võib käsitleda jutustuse mitmetasandilisuse mudeli abil. Selle lähenemisviisi kohaselt realiseerub tekstides jutustuslikkus mitmel tasandil, mis koos moodustavad teksti jutuainese. Lisaks sündmuslugudele sisaldavad kirjalikud jutustused ka selliseid kirjeldusi, mis on kas liialt fragmentaarsed (näiteks viited loo motiividele) või liiga ulatuslikud ja mitmekihilised selleks, et vastata iseseisva loo kriteeriumitele. Ka korduva tegevuse kirjeldamine jutustavas vormis kaldub lihtsa jutustuse ideaalist kõrvale. Teksti ebatüüpilisi jutustamislaade, nagu ka anekdoodilaadseid lugusid, ühendab kirjalik vorm. Tekst on kõigesööja: see ei ole mitte ainult žanridest koosnev žanr, vaid erinevatest jutustusviisidest koosnev jutustus. Sellegipoolest ei saa teksti kõiki osi pidada ühe ja sama jutustuse osadeks ning isegi mitte tingimata üldse jutu osadeks, vaid näiteks tekstist sündinud dialoogi osadeks. Näiteks lugeja suunamine teksti juurde ja saatesõnad või kaaskiri on sellised kujuteldava dialoogi osad, mis ahvatlevad kirjutist käsitlema pigem sõnavõtu kui jutustusena.

Žanrid suunavad lugemist ja teksti tõsieluseoste tõlgendamist. Teisalt seovad žanrid kirjutisi laiemate intertekstuaalsete raamidega, väljendusviiside 
traditsioonidega. Narratiivsust kui kogumisvõistluste tekstide omadust võib mõista väljaspool jutustusi oleva diskursusena, suure loona, millega üksikud jutud on intertekstuaalses seoses. Suured lood moodustavad meie tõsielutunnetuse narratiivse osa, millele argielu väiksed lood viitavad taustoletustena (Lyotard 1985; 1989). Suure loo mõiste abil saab näiteks liigendada kirjeldusi naise ja mehe ideaalsest elukäigust meie kultuuris (partneri leidmine - abiellumine - laste saamine - surm lugupeetud vanurina) ning jälgida seda, mil määral erinevad elulookirjeldused kordavad või eitavad sellist tõlgendusraami.

\section{Lõpetuseks}

Lõpetuseks käsitlen veel üht kogumisvõistluste ja intervjuuprojektide kaudu saadud materjalide tüüpilist erinevust, mis on nende tekstide tõlgendamise seisukohast oluline. Nimetan seda samaviitelisuse probleemiks, kus probleemi moodustab nimelt samaviitelisuse puudumine. Samaviitelisuse puudumine on tingitud kogumisvõistluste korraldusest ja mitte kuigivõrd materjali loomisviisist.

Kirjutamisvõistlused on tavaliselt suunatud laiale üldsusele, näiteks kogu soomekeelsele elanikkonnale. Saadud vastused seostuvad sellisel juhul erinevate kogukondadega erinevates kohtades ja erinevatel aegadel. Tõlgenduse seisukohalt kaasneb sellega sporaadilisuse (hajususe, eraldatuse, eriviitelisuse) probleem (vt Virtanen 1993: 10-11): eraldiseisvalt saadud kirjeldused ei paku võimalust ajaloolise tõe selliseks läbivalgustamiseks, mis on nii võluvalt omane suulise ajaloo parimatele monograafiatele. Kõige paremini sobivad kogumisvõistluste tekstid erinevate vaatenurkade ja käsitluste skaala väljaselgitamiseks (vrd Apo 2001: 17). Kuidas need käsitlused suletud kollektiivides, kirjutajate konkreetsetes elukeskkondades jne suhestuvad omavahel, seda vastused eriti ei peegelda. Kahte samasse ühiskonda paigutuvat, kuid üksteisest sõltumatut kirjeldust sellisest materjalist tavaliselt leida ei õnnestu. ${ }^{20}$

Suulise ajaloo intervjuuprojektide puhul on olukord enamasti praktilistel põhjustel teine: intervjueerijad töötavad piiritletud territooriumil ja liiguvad piiritletud inimhulga keskel, otsides intervjueeritavaid, järgides sotsiaalse võrgustiku sõlmpunkte (nn lumepallimeetod). Ja kuigi projekti lähtekohaks ei pruugi tingimata olla etnograafilise välitöö holistlike ideaalide rakendamine või isegi tundmine, on paljud suulise ajaloo uurimise tööpõllud olnud tegelikult piiritletud ühiskonnad, territoriaalsed tervikud, vabriku töökollektiivid või perekonnad. Sellise ühiskonna liikmete intervjuudesse ilmub vältimatult oluline joon, mis tavaliselt kirjalikes jutustustes puudub: samadest objekti- 
dest rääkimine, mida nimetangi samaviitelisuseks. Tänu samaviitelisusele on võimalik uurida ka teistsugust kogemuslikkuse skaalat: mitte kõikvõimalike kogemisviiside spektrit, vaid erinevate, omavahel konkureerivate kogemis- ja tõlgendusviiside võrgustikku.

Põhimõtteliselt ei takista miski korraldamast kirjutamisvõistlusi või küsitlust, mille objektiks on piiritletud territoriaalne või sotsiaalne tervik: näiteks linn, vabrik või kooliklass. Kui sellist materjali õnnestub koguda piisavalt katva valimina, võib see tõlgenduslikult läheneda suulise intervjueerimistraditsiooni parimatele näidetele ning heita valgust nii (biograafilise) ajaloo tõe subjektiivsele olemusele kui ka kohaliku ajaloo minakesksele lokaliseerumisele. Miski ei takista ka kirjeldatud uurimisviiside ühendamist: kirjutamisvõistlustel osalenute edasist intervjueerimist ja intervjueeritute ärgitamist näiteks ise oma elulugu kirja panna. ${ }^{21}$ Teaduslikust uurijahuvist lähtuva kogumistöö korraldamine kvantitatiivse kogumise asemel eeldab, et fookuses olevaid teadusprobleeme käsitletaks ka kogumisvõistlusi korraldavates arhiivides: milliste nähtuste kohta soovime rohkem teada saada, miks, milliste vahenditega? Sellisel juhul ei toimi kirjutamine ja intervjueerimine vastanditena, vaid üksteist täiendavate meetoditena, mida andekas teadlane (kujuteldav ideaalsubjekt) oskab kohandatult oma projektis rakendada. ${ }^{22}$

Tõlkinud Kadri Jaanits

\section{Kommentaarid}

${ }^{1}$ Originaal: Jyrki Pöysä. Kilpakirjoitukset muistitietotutkimuksessa. Fingerroos, Outi \& Haanpää, Rina \& Heimo, Anne \& Peltonen, Ulla-Maija (toim). Muistitietotutkimus: metodologisia kysymyksiä. Tietiolipas 214. Helsinki: SKS, lk 221-244. Artikkel on tõlgitud autori ja kogumiku toimetuse loal.

2 Pärimusliku ajaloo uurimist võib sellisel juhul vaadelda osana laiemast kontekstist, mille raames käsitletakse akadeemilise ajaloo uurimise traditsioonist väljapoole jäävaid mineviku kirjeldamise viise. Vt nt Rosenzweig \& Thelen 1998; Lowenthal 1999.

3 Materjali kasutusväärtust on mitmetes metodoloogiaalastes ettekannetes käsitlenud nt Grönfors 1982; Roos 1988; Apo 1993; 1995; 2001; Ukkonen 2000; Eskola \& Suoranta 2003; Helsti 2005. Rahvusvahelistes metoodikakäsiraamatutes käsitletakse uurija enda algatusel loodud autobiograafiliste tekstide kasutusväärtust harva - need jäävad spontaanselt sündinud nn isiklike dokumentide varju (vt ka Johnstone 2000).

${ }^{4}$ Kogumisvõistluste või rahvaluulearhiivi kaastöölistele saadetud küsitluste materjalide põhjal tehtud uurimustöödest ja esseedest võiks mainida nt Roos 1987; Piela 
1993; Siltala 1994; Rantala 1995; Peltonen 1996; Vilkko 1997; Pöysä 1997; Apo 2001; Huttunen 2002; Nirkko \& Vesala 2004; Latvala 2005.

5 Ei tohi unustada, et on ka teistsuguseid kirjalikke materjale, mis arhiivis ja teaduslikus kasutuses suhestuvad siinkäsitletavatega. Ma ei pea siinkohal silmas isiklikke dokumente ega käsitsi kirjutatud ajalehti, vaid intervjuude litereeringuid ja referaate (lindistuste kokkuvõtteid) ning kogumisel kirja pandud rahvaluulet ja etnograafilist teavet peamiselt perioodist, mil teistsugused salvestusmeetodid ei olnud veel kättesaadavad. Kogumisprotsessi vältel kirja pandud pärimust võib leida ka kogumisvõistluste materjalide hulgas, seda juhul, kui koguja on teisi, näiteks oma endisi töökaaslasi intervjueerides nende kogemusi täiendanud (vt Pöysä 1997: $54-55)$.

6 "Kirjutava jutustaja" mõiste ei pruugi tingimata olla arusaadav teistele peale folkloristide, kellele oli veel 1980. aastatel rahvaluule ehk folkloori ehedaks olekuks suuline kultuur ning kes püüdlevad selle poole, et jätta vaatluse alt välja informantide (ehk jutustajate) kirjalik tegevus. "Teemakirjutis" või "temaatiline kirjutis" on tuletatud "teemaintervjuu" mõistest, mis sotsiaal- ja kasvatusteadustes märgib lõdvalt struktureeritud (kuid mitte päris avatud) intervjuud (vt Hirsjärvi \& Hurme 2000).

7 Vrd raskestitõlgitavat ingliskeelset terminit elicited mõistes elicited written data (Johnstone 2000: 121-123).

${ }^{8}$ Kuigi käesolev artikkel käsitleb eelkõige kogumisvõistluste käigus saadud materjale, sobivad tehtud tähelepanekud põhiosas ka küsitlustega saadud materjalide kohta. Rahvaluulearhiivi kirjasaatjate võrgule saadetud küsitlustes on sarnaselt kogumisvõistlustele kirjutajatel palutud vastata avatult, mis on selgesti erinev näiteks tarbijauuringutes kasutatud täpselt struktureeritud küsitlusankeetidest.

9 Soome arhiivide eluloomaterjalide ja nende kogumiseajaloo kohta vt Peltonen 1987.

${ }^{10}$ Vt nt Laaksonen 1978; Nirkko 1999. Kogumisprojektide ja nende käigus saadud materjalide loetelu on avaldatud Soome Kirjanduse Seltsi kodulehel http:// www.finlit.fi (vt ka Laaksonen \& Saarinen 2004: 14-30, 132-135).

11 Teksti toimetatavus varieerub paljuski siiski kirjutamistehnoloogiast sõltuvalt kas kirjutatakse nt pastapliiatsi või tekstitöötlusprogrammiga, vt Chandler 1992.

${ }^{12}$ Mihhail Bahtini dialoogilisuse põhimõtete kohta vt Todorov 1984. Dialoogilisuse puhul ei ole küsimus ainult selles, et rääkimine toimub mõlemapoolse kommunikatsioonina (ja et kõnekeel on oma olemuselt dialoogiline, mitte monoloogiline). Laiemas mõttes tähendab dialoogilisus vastuvõtjate, eeldatavate lugejate (või kuulajate) lülitumist teksti. Intervjuu puhul toob eelkõige diktofoni või mõne teise salvestusvahendi kohalolek kõnesse pöördumise kolmandate isikute poole, kuulajate poole, kes potentsiaalselt osalevad kommunikatsioonis mõnel hilisemal ajahetkel. Kirjutades on selline "kolmas" kaasatud kommunikatsiooni algusest peale, teksti oletatava vastuvõtjana.

${ }^{13}$ Suulise ajaloo omadust siduda erinevaid žanre on oma töödes käsitlenud nt Elisabeth Tonkin (1992), Luisa Passerini (1987). Vt ka Cándida Smith 2002, kes analüüsib Luisa Passerini uurimustes esinevaid suulise ajaloo materjalide tõlgendamise viise.

${ }^{14}$ Mihhail Bahtini järgi on komplekssed žanrid kirjanduslikud žanrid, mis võivad sisaldada suulise kultuuri "lihtsaid" žanre (Bahtin 1986; Todorov 1984; vt ka Latvala 2005: 31; Gullestad 1996: 5-6, 35-36). 
${ }^{15}$ Portelli esitab oma artiklis teisigi žanrijaotusi, muu hulgas lihtsa temaatilise jaotuse (meeste) sõjalugude ja (naiste) haiglalugude põhjal (Portelli 1998: 26-27). Suulise ajaloo žanri ja suulises ajaloos sisalduvate žanride kohta vt Chamberlain \& Thompson 1998.

${ }^{16}$ Pauliina Latvala on oma väitekirjas käsitlenud kogumisvõistlustel osalenute kirjanduslikke jutustamisviise, liigendades nende jutustamisviiside aluseks olnud mudelid viide rühma: elust jutustamise mudelid, ajaloost jutustamise mudelid, põlvkondadest jutustamise mudelid, fiktiivsed mudelid ja suulise jutustamise mudelid (Latvala 2005: 72-78). Selle kogumisvõistluste teemaga seotud erijoontest "puhastatud" jaotust oleks huvitav rakendada ka teiste kogumisvõistluste käigus saadud materjalide analüüsil.

${ }^{17}$ Vastamisjuhiste ehk kogumisüleskutsete kui omaette žanri ülesehitust ja sõnastuste reeglistumist on võimalik jälgida rohkem kui saja aasta vältel (vt Pöysä \& Timonen 2004). Seegi on huvitav, et kõnesolev kirjaliku reeglistiku säilitamine toimub peamiselt suulisena: arhiivitöötajate nõuannetena kogumisvõistluste korraldajatele kogumise kavandamisel ja üleskutsete toimetamisel. Mingisuguseid kirjalikke juhiseid hea üleskutse koostamiseks ei ole vormistatud.

${ }^{18}$ Siiski olen näinud kirjanduses viidatavat ainult ühele antoloogiale ja selgi juhul reservatsioonidega, vt Soikkeli 2002: 20-21.

${ }^{19}$ Antoloogiate toimetamispõhimõtete üle oli huvitav diskussioon 1980. aastate alguses, kui Satu Apo (1980) andis kriitilise hinnangu Terttu Kaivola toimetatud kogumikule rahvaluulearhiivi Kivennapa materjalidest (Kaivola 1979). Põhiprobleemina tõi Satu Apo esile avaldatud materjali liigse heterogeensuse ja tekstide banaalsuse, mida tema sõnutsi oleks saanud vältida, kui tekste oleks rohkem toimetatud või välja jäetud väljendusvaesed kirjeldused.

${ }^{20}$ Kahe üksteisest sõltumatu kirjelduse kriteerium võiks viidata ka folkloori tehnilisele definitsioonile: sama loo kohta peab olema talletatud vähemalt kaks üksteisest sõltumatut varianti, enne, kui neid võib lugeda folklooriks, mitte üksikvastaja erineval ajal esitatud samaks narratiiviks. Samaviitelisuse puhul on siiski tegemist teise nähtusega. See tähistab ühiskondlike seoste ja vaatenurkade erinevust ühe ja sama nähtuse, inimese või sündmuse suhtes. Vaatenurkade varieerumine muudab näiteks Oscar Lewise monograafia Sanchezi lapsed (Lewis 1975) ainulaadseks kirjelduseks suletud ühiskonna liikmete ühisest reaalsusest või õigemini sama reaalsuse subjektiivsest killustatusest erinevateks osareaalsusteks.

${ }^{21}$ Professor Pekka Laaksonen on oma töödes ja ettekannetes seda alternatiivi korduvalt soovitanud, toetudes üle kolmekümne aasta pikkusele arhiivijuhataja kogemusele kogumisvõistluste materjalidega.

${ }^{22}$ Lõpetuseks soovin tänada kommentaaride eest PhD Taina Ukkoneni ja kasulike nõuannete eest $\mathrm{PhD}$ Sinikka Vakimot. Juhani Hesikaneni tänan tähelepanu pööramise eest prosoodia ja värsimõõdu teemale. 


\section{Kirjandus}

Apo, Satu 1980. Perinnekirjan toimittamisesta. Suomen Antropologi 5 (1), lk 49.

Apo, Satu 1993. Kirjoittavat kertojat. Teemakirjoittaminen - folkloristiikan "näkymätön“ aineistonhankintamenetelmä. Elias 4, lk 12-15.

Apo, Satu 1995. Naisen väki:Tutkimuksia suomalaisten kansanomaisesta kulttuurista ja ajattelusta. Helsinki: Hanki ja Jää.

Apo, Satu 2001. Viinan voima: Näkökulmia suomalaisten kansanomaiseen alkoholiajatteluun ja -kulttuuriin. Suomalaisen Kirjallisuuden Seuran Toimituksia 759. Helsinki: Suomalaisen Kirjallisuuden Seura.

Bahtin 1986 = Бахтин, Михаил. Проблема речевых жанров. Бахтин, Михаил (toim). Литературно-критические статьи. Москва: Художественная литература, lk 428 - 472 (http://philologos.narod.ru/bakhtin/bakh_genre.htm - 9. oktoober 2009).

Bauman, Richard \& Briggs, Charles L. 1990. Poetics and Performances as Critical Perspectives on Language and Social Life. Annual Review of Anthropology 19, lk 59-88.

Beiner, Guy 1999. Bodhaire Ui Laoire: Oral History and Contemporary Irish Historiography (http://www.ucd.ie/pages/99/articles/beiner.html - 8. oktoober 2009).

Cándida Smith, Richard 2002. Analytic Strategies for Oral History Interviews. Gubrium, Jaber F. \& Holstein, James A. (toim). Handbook of Interview Research. Context and Method. Thousand Oaks (California): Sage.

Chafe, Wallace \& Danielewicz, Jane 1987. Properties of Spoken and Written Language. Horowitz, Rosalind \& Samuels, S. Jay (toim). Comprehending Oral and Written Language. New York: Academic Press, lk 83-113.

Chafe, Wallace and Tannen, Deborah 1987. The Relation between Written and Spoken Language. Annual Review of Anthropology 16: 1k 383-407.

Chamberlain, Mary \& Thompson, Paul (toim) 1998. Narrative and Genre. London Routledge.

Chandler, Daniel 1992. The Phenomenology of Writing by Hand (http://www.aber.ac.uk/ media/Documents/short/phenom.html- 8. oktoober 2009).

Dunaway, David K. 1996. Introduction: The Interdisciplinarity of Oral History. Dunaway, Dacid K. \& Baum, Willa K. (toim). Oral History: An Interdisciplinary Anthology. London: Altamira Press.

Eskola, Jari \& Suoranta, Juha 2003. Johdatus laadulliseen tutkimukseen. Tampere: Vastapaino.

Fingerroos, Outi 2004. Haudatut muistot. Rituaalisen kuoleman merkitykset Kannaksen muistitiedossa. Suomalaisen Kirjallisuuden Seuran Toimituksia 985. Helsinki: Suomalaisen Kirjallisuuden Seura.

Fingerroos, Outi \& Haanpää, Riina 2006. Muistitietotutkimuksen ydinkysymyksiä. Fingerroos, Outi \& Haanpää, Riina \& Heimo, Anne \& Peltonen, Ulla-Maija (toim). 
Muistitietotutkimus. Metodologisia kysymyksiä. Tietolipas 214. Helsinki: Suomalaisen Kirjallisuuden Seura, lk 25-48.

Fludernik, Monika 2000. Genres, Text Types, of Discourse Modes? Narrative Modalities and Generic Categorization. Style 34 (2), lk 274-292.

Grönfors, Martti 1982. Kvalitatiiviset kenttätyömenetelmät. Helsinki: WSOY.

Gullestad, Marianne 1996. Everyday Life Philosophers: Modernity, Morality, and Autobiography in Norway. Oslo: Scandinavian University Press.

Hanks, William F. 1989. Text and Textuality. Annual Review of Anthropology 18, lk 95127.

Helsti, Hilkka 2005. Hedelmällisen tiedon jäljillä. Teemakirjoitukset tutkimuksen lähteenä. Korkiakangas, Pirjo \& Olsson, Pia \& Ruotsala, Helena (toim). Polkuja etnologian menetelmiin. Ethnos-toimite 11. Helsinki: Ethnos ry, lk 148-159.

Hirsjärvi, Sirkka \& Hurme, Helena 2000. Tutkimushaastattelu: Teemahaastattelun teoria ja käytäntö. Helsinki: Helsinki University Press.

Huttunen, Laura 2002. Kotona, maanpaossa, matkalla: Kodin merkitykset maahanmuuttajien elämäkerroissa. Suomalaisen Kirjallisuuden Seuran Toimituksia 861. Helsinki: Suomalaisen Kirjallisuuden Seura.

Hyvärinen, Matti 2005. Kertomuksen tuolla puolen. Kovala, Urpo \& Eskola, Katarina \& Jokinen, Kimmo \& Niinikangas, Vesa \& Sironen, Esa (toim). Tarkkoja siirtoja (http:/ /www.arthis.jyu.fi/julkaisut/tarkkojasiirtoja/hyvarinen.html - 8. oktoober 2009).

Hyvärinen, Matti \& Peltonen, Eeva \& Vilkko, Anni (toim) 1998. Liikkuvat erot: Sukupuoli elemäkertatutkimuksessa. Tampere: Vastapaino.

Ikonen, Hanna-Mari \& Ojala, Hanna 2005. Yhteisyyden luomista ja eronkokemuksia - haastattelu, konteksti ja feministinen tietäminen. Naistutkimus = Kvinnoforsking 18 (1), lk 17-29.

Johnstone, Barbara 2000. Qualitative Methods in Sociolinguistics. Oxford: Oxford University Press.

Kaarlenkaski, Taija \& Kupiainen, Karolina \& Pankamo, Heidi \& Pyykkönen, Pirita \& Pöysä, Jyrki 2005. Joensuun paikat. Kultaneito 5. Joensuu: Suomen Kansantietouten Tutkijain Seura.

Kaivola, Terttu (toim) 1979. Kivennavalla. Karjalaisia kertomuksia ja muistikuvia. Kansanelämän kuvauksia 11. Helsinki: Suomalaisen Kirjallisuuden Seura.

Karumo, Markku (toim) 2004. Erikoinen tapaus. Helsinki: Helsingin Sanomat (http:// www.hs.fi/extrat/erikoinentapaus/ - 8. oktoober 2009).

Kauppinen, Anneli \& Laurinen, Leena 1984. Tekstejä teksteistä. Muisti- ja tekstilingvistiikan sovelluksia asiatekstien referoinnin problemaatiikkaan. Suomalaisen Kirjallisuuden Seuran Toimituksia 412. Helsinki: Suomalaisen Kirjallisuuden Seura.

Korkiakangas, Pirjo 2005. Muistoista tulkintaan - muisti ja muisteluaineistot etnologian tutkimuksessa. Korkiakangas, Pirjo \& Olsson, Pia \& Ruotsala, Helena (toim). Polkuja etnologian menetelmiin. Helsinki: Ethnos ry, lk 129-147. 
Laaksonen, Pekka 1978. Finska Litteratursällskapets (SKS) folkminnesarkivs praktiska och ideologiska problem. Ark \& Dok 2. NIF Publications 6. Turku: The Nordic Institute of Folklore.

Laaksonen, Pekka \& Saarinen, Jukka (toim) 2004. Arkiston avain. Kansanrunousarkiston kortistot, hakemistot, luettelot, lyhenteet. Suomalaisen Kirjallisuuden Seuran Toimituksia 1003. Helsinki: Suomalaisen Kirjallisuuden Seura.

Latvala, Pauliina 2005. Katse menneisyyteen: Folkloristinen tutkimus suvun muistitiedosta. Suomalaisen Kirjallisuuden Seuran Toimituksia 1024. Helsinki: Suomalaisen Kirjallisuuden Seura.

Lejeune, Philippe 1989. On Autobiography. Minneapolis: University of Minnesota Press. Lewis, Oscar 1975. Sanchezin lapset. Helsinki: WSOY.

Lowenthal, David 1999 (esitrükk 1985). The Past is a Foreign Country. Cambridge: Cambridge University Press.

Lyotard, Jean-Francois 1985. Tieto postmodernissa yhteiskunnassa. Tampere: Vastapaino.

Lyotard, Jean-Francois 1989. Lessons in Paganism. Benjamin, Andrew (toim). The Lyotard Reader. Oxford: Blackwell, lk 122-154.

Nirkko, Juha 1999. Life-Story materials in the Folklore Archives. FF Network 18 (November), $1 \mathrm{k} 23-24$.

Nirkko, Juha \& Vesala, Kari 2004. Kirjoituksia maan sydämeltä:Tutkimusnäkökulmia maanviljelijöiden kilpakeruuaineistoon. Suomalaisen Kirjallisuuden Seuran Toimituksia 931. Helsinki: Suomalaisen Kirjallisuuden Seura.

Oinas, Elina 2004. Haastattelu: kokemuksia, kohtaamisia, kerrontaa. Liljeström, Marianne (toim). Feministinen tietäminen: Keskustelua metodologiasta. Tampere: Vastapaino.

Passerini, Luisa 1987. Fascism in Popular Memory: The Cultural Experience of the Turin Working Class. Cambridge: Cambridge University Press.

Peltonen, Ulla-Maija 1985. Työväen muistitieto ja perinne: Selvitys työväen muistitiedon ja perinteen keruusta ja arkistoinnista sekä esitys työväen muistitiedon ja perinteen sisältöanalyysimalliksi. Helsinki: Työväenperinne - Arbetartradition.

Peltonen, Ulla-Maija 1987. Arkistojen elämäkerta-aineistoista. Arkisto. Arkistoyhdistyksen julkaisuja 2. Helsinki: Arkistoyhdistys, lk 123-134.

Peltonen, Ulla-Maija 1996. Punakapinan muistot:Tutkimus työväen muistelukerronan muotoutumisesta vuoden 1918 jälkeen. Suomalaisen Kirjallisuuden Seuran Toimituksia 657. Helsinki: Suomalaisen Kirjallisuuden Seura.

Piela, Ulla (toim) 1993. Aikanaisia: Kirjoituksia naisten omaelämäkerroista. Tietolipas 127. Helsinki: Suomalaisen Kirjallisuuden Seura.

Portelli, Alessandro 1998. Oral History as Genre. Chamberlain, Mary \& Thompson, Paul (toim). Narrative and Genre. London: Routledge, lk 23-45. 
Pöysä, Jyrki 1997. Jätkän synty. Tutkimus sosiaalisen kategorian muotoutumisesta suomalaisessa kulttuurissa ja itäsuomalaisessa metsätyöperinteessä. Suomalaisen Kirjallisuuden Seuran Toimituksia 669. Helsinki: Suomalaisen Kirjallisuuden Seura.

Pöysä, Jyrki 2003. Tietokone - isäntä vai renki? Analyysi retrospektiivisen muistelun rakenteista kilpakirjoitusaineistossa. Talja, Sanna \& Tuuva, Sari (toim). Tietotekniikkasuhteet. Kulttuurien näkökulma. Tietolipas 196. Helsinki: Suomalaisen Kirjallisuuden Seura, lk 148-194.

Pöysä, Jyrki \& Timonen, Senni 2004. Kuinka ahkerat muurahaiset saivat kasvot? Henkilökohtaisen tiedon paikka arkiston keruuohjeissa. Kurki, Tuulikki (toim). Kansanrunousarkisto, lukijat ja tulkinnat. Suomalaisen Kirjallisuuden Seuran Toimituksia 1002. Helsinki: Suomalaisen Kirjallisuuden Seura, lk 218-254.

Rantala, Irma 1995. Eläköön mies! Essee miesten omaelämäkerta-aineistoasta. Elektroloristi 2 (1) (http://cc.joensuu.fi/ loristi/1_95/ran.195.html - 8. oktoober 2009).

Rintala, Paavo 1966. Sotilaiden äänet. Kannaksen läpimurtotaisteluista 1944. Yleisradion ääniarkistosta koonnut Paavo Rintala. Helsinki: Weilin + Göös.

Rintala, Paavo 1967. Sodan ja rauhan äänet. Helsinki: Otava.

Roos, Jeja-Pekka 1987. Suomalainen elämä: tutkimus tavallisten suomalaisten elämäkerroista. Suomalaisen Kirjallisuuden Seuran Toimituksia 454. Helsinki: Suomalaisen Kirjallisuuden Seura.

Roos, Jeja-Pekka 1988. Elämäkerta, omaelämäkerta, tosi elämä. Johdanto sosiologiseen elämäkertatutkimukseen. Roos, Jeja-Pekka, Elämätavasta elämäkertaan Elämäntapaa etsimässä 2. Helsinki: Tutkijaliitto.

Rosenzweig, Roy \& Thelen, David 1998. The Presence of the Past. Popular Uses of History in American Life. New York: Columbia University Press.

Siltala, Juha 1994. Miehen kunnia. Modernin miehen taistelu häpeää vastaan. Helsinki: Otava.

Soikkeli, Markku 2002. Johdatus 1900-luvun kotimaisen kirjallisuuteen. Soikkeli, Markku (toim). Kurittomat kuvitelmat. Johdatus 1900-luvun kotimaiseen kirjallisuuteen. Sarja A, 50. Turku: Turun yliopiston taiteiden tutkimuksen laitos.

Thompson, Paul 1978. The Voice of the Past. Oral History. Oxford: Oxford University Press.

Todorov, Tzvetan 1984. Mikhail Bakhtin. The Dialogical Principle. Theory and History of Literature 13. Minneapolis: The University of Minnesota Press.

Todorov, Tzvetan 1990. Genres in Discourse. Cambridge: Cambridge University Press.

Tonkin, Elisabeth 1992. Narrating Our Pasts: The Social Construction of Oral History. Cambridge: Cambridge University Press.

Tõnjanov 2001 = Tynjanov, Juri 2001 (esitrükk 1929). Kirjallinen tosio. Pesonen, Pekka \& Suni, Timo (toim). Venäläinen formalismi. Antologia. Tietolipas 172. Helsinki: Suomalaisen Kirjallisuuden Seura, lk 233-254. 
Ukkonen, Taina 2000. Menneisyyden tulkinta kertomalla. Muistelupuhe oman historian ja kokemuskertomusten tuottamisprosessina. Suomalaisen Kirjallisuuden Seuran Toimituksia 797. Helsinki: Suomalaisen Kirjallisuuden Seura.

Ukkonen, Taina 2006. Yhtesityö, vuorovaikutus ja narratiivisuus muistitietotutkimuksessa. Fingerroos, Outi \& Haanpää, Riina \& Heimo, Anne \& Peltonen, Ulla-Maija (toim). Muistitietotutkimus. Metododologisia kysymyksiä. Tietolipas 214. Helsinki: Suomalaisen Kirjallisuuden Seura, lk 175-198.

Vilkko, Anni 1997. Omaelämäkerta kohtaamispaikkana. Naisen elämän kerronta ja luenta. Suomalaisen Kirjallisuuden Seuran Toimituksia 663. Helsinki: Suomalaisen Kirjallisuuden Seura.

Virtanen, Leea 1982. Henkilökohtainen kerronta. Knuuttila, Seppo \& Järvinen, IrmaRiitta (toim). Kertomusperinne. Tietolipas 90. Helsinki: Suomalaisen Kirjallisuuden Seura, lk 171-205.

Virtanen, Leea 1993. Ovatko perinnearkistot aarreaittoja? Elias 4, lk 8-11.

Virtanen, Tuija 1992. Issues of Text Typology: Narrative - a Basic Type of Text? Text 12 (2), lk 293-310.

\title{
Summary
}

\section{Memoir Writing Competitions in Oral History Research}

\author{
Jyrki Pöysä
}

Key words: collection competition, interview of oral history, life history research, narrative genre, oral history, oral and written culture (remembering), oral narrative history, written contributions to collection competitions

Oral history traditionally involves the research of oral interviews. The article raises the question of how the starting points of research change when memories are not told in an oral interview but are presented in written form.

Finnish oral history research tradition involves collecting material by means of open competitions, in the course of which voluntary contributors send their written memories to the archive. Relying on experience derived from the study of written texts, the author first analyses how both the 'situation of remembering' and the 'instrument' for recording memories affect the process of remembering. The article introduces two methods that permit the systematisation of heterogeneous text material obtained as a result of memoir writing competitions. Extended genre analysis gives the researcher an opportunity to describe literary features that are characteristic of the texts. The form that the writer has selected also provides clues about how to interpret the content and information about the writer's attitude towards his or her task. The article observes the multiple themes in the text by employing narrative analysis. 
Writing competitions are usually targeted at the general public. Contributions sent to the competition can be associated with different communities. Therefore the collected material can be quite sporadic, which is not characteristic of oral interview texts recorded in a community of researcher's choice. The texts of writing competitions enable researchers to determine the range of approaches and points of view rather than to study the beliefs of a specific community. 